\title{
Investigating the effects of relaxation therapy on decreasing anxiety in patients with elective caesarean section in Imam Khomeini Hospital, Ahvaz, Iran during 2016
}

\author{
Badanie skutków zastosowania technik relaksacyjnych w zakresie zmniejszenia \\ lęku u pacjentek poddanych planowemu cięciu cesarskiemu w Szpitalu \\ imama Chomejniego w Ahwazie w Iranie w 2016 roku
}

\author{
Masoumeh Nazarinasab¹, Azim Motamedfar ${ }^{1}$, Mahin Najafian², Hoorasa Tabibi³ \\ ${ }^{1}$ Department of Radiology, Golestan Hospital, Ahvaz Jundishapur University of Medical Sciences, Ahvaz, Iran \\ 2Department of Obstetrics and Gynaecology, School of Medicine, Ahvaz Jundishapur University of Medical Sciences, Ahvaz, Iran \\ ${ }^{3}$ Student Research Committee, Ahvaz Jundishapur University of Medical Sciences, Ahvaz, Iran
}

Key words: relaxation therapy, anxiety, patients with elective caesarean section, Ahvaz Imam Khomeini hospital.

Słowa kluczowe: techniki relaksacyjne, lęk, pacjentki poddane planowemu cięciu cesarskiemu, Szpital imama Chomejniego w Ahwazie.

\begin{abstract}
Introduction: Caesarean section, due to delivery and operating room and anaesthesia as well as well-known complications for the patient, can cause anxiety in patients, and this anxiety creates physical problems for the patient.

Aim of the research: To investigate the effects of relaxation therapy on decreasing anxiety in patients with elective caesarean section. Material and methods: This clinical trial was conducted on 90 pregnant women (45 persons in each of two groups), aged 20 to 35 years old, who underwent elective caesarean section in Imam Khomeini Hospital, Ahvaz, Iran during 2016. In the muscle relaxation intervention group, progressive relaxation was performed for $20-25 \mathrm{~min}$. These activities were performed every hour for a total of four times before the surgery. For the control group, neutral contents (e.g. benefits of vegetables and fruits) that were prepared as pamphlets were distributed, and no other intervention was performed. The data were collected using the Hamilton Anxiety Rating Scale (HAM-A).

Results: The results showed that explicit anxiety in the intervention group was significantly lower than in the control group, but the groups did not show any significant difference in implicit anxiety. However, relaxation therapy decreased total anxiety in pregnant women prior to caesarean section. Regarding anxiety after caesarean section, the condition was similar, and this technique could decrease implicit anxiety and total anxiety of women. In addition, both groups showed no significant difference between the anxiety pre- and post caesarean section, indicating that the anxiety of women continued after caesarean section.

Conclusions: The findings showed that relaxation therapy decreases anxiety levels of pregnant women under caesarean section and can be used to decrease stress and anxiety of mothers.
\end{abstract}

\section{Streszczenie}

Wprowadzenie: Cesarskie cięcie ze względu na poród, salę operacyjną i znieczulenie oraz dobrze znane powikłania może u pacjentek wywoływać lęk, który wpływa niekorzystnie na ich stan fizyczny.

Cel pracy: Zbadanie skutków zastosowania technik relaksacyjnych w zakresie zmniejszania lęku u pacjentek poddanych planowemu cięciu cesarskiemu.

Materiał i metody: Badanie kliniczne przeprowadzono u 90 kobiet w ciąży (dwie grupy po 45 osób) w wieku od 20 do 35 lat, które w 2016 r. przeszły planowe cięcie cesarskie w Szpitalu imama Chomejniego w Ahwazie w Iranie. W grupie badanej zastosowano metode progresywnej relaksacji przez 20-25 minut. Zajęcia przeprowadzano co godzinę, łącznie 4 razy przed operacją. W grupie kontrolnej rozdano broszury zawierające neutralne treści (np. dotyczące korzyści ze spożywania warzyw i owoców) i nie wprowadzono żadnej innej interwencji. Dane zebrano przy użyciu Skali oceny lęku Hamiltona (HAM-A). Wyniki: Stwierdzono, że jawny lęk w grupie badanej był znacznie mniejszy niż w grupie kontrolnej, ale nie wykazano istotnych różnic w zakresie ukrytego lęku. Techniki relaksacyjne zmniejszyły całkowity lęk u kobiet w ciąży przed cięciem cesarskim. W przypadku lęku po cięciu cesarskim stan był podobny, a techniki relaksacyjne mogły zmniejszyć niejawny lęk i ogólny lęk kobiet. Ponadto w obu grupach nie stwierdzono istotnej różnicy między lękiem przed cięciem cesarskim i po cięciu cesarskim, co wskazuje, że lęk u kobiet utrzymywał się po cięciu cesarskim.

Wnioski: Techniki relaksacyjne u kobiet w ciąży zmniejszają poziom lęku związanego z cięciem cesarskim i mogą być stosowane w celu zmniejszenia stresu i lęku matek. 


\section{Introduction}

Anxiety is a response against unknown, internal, and ambiguous danger [1], which is characterised by one or more physical indexes such as feeling dizzy, shortness of breath, heartbeat, sweating, headache, urination, and desire to move [2]. Caesarean section, due to the delivery and operating room and anaesthesia as well as well-known complications for the patient, can cause anxiety in patients, and this anxiety creates physical problems for the patient.

Medical and behavioural methods are among the most effective methods to control and decrease anxiety [3]. The most commonly used drugs for the treatment of anxiety include benzodiazepines, tetracyclic antidepressants, monoamine oxidase inhibitors, serotonin reuptake inhibitors, non-benzodiazepine anxiolytics, carbamazepine, propranolol, and hydroxyzine [4]. The drugs, despite having rapid effects, have many complications and should not be used for eight to 12 months, and in most cases anxiety increases again. One of the complications of these drugs is creating dependence if consumed for a long-term period [5]. So we can't use drug now as safe drug because causes deprivation symptoms including anxiety, susceptibility, fatigue, headache, insomnia, dizziness, depression, delusions, and seizures [6].

Behavioural therapeutic methods are non-drug methods to decrease anxiety, including therapeutic touch, the use of heat and cold, and various relaxation methods (hypnosis, guided imagery, deviation, biofeedback, meditation, yoga, progressive muscle relaxation, and Benson Muscle Relaxation). These methods, in addition to their safe and low-cost nature, are non-invasive [7].

Muscle relaxation significantly changes the functioning of the automatic nervous system; as a result, it influences physiological reactions to stress. Therefore, oxygen consumption and $\mathrm{CO}_{2}$ production are decreased, heartbeat and number of breaths are decreased, and pleasant feelings and intellectual concentration are increased. Another non-drug intervention to decrease stress is music therapy, in which rhythmic sound is used to create communication and relaxation $[8,9]$. Although this method is non-invasive and cost-effective without any complications, it has some limitations. For example, in this method, the patient must take an active role and performs orders actively in all steps. Another method that is used in different countries to decrease anxiety is therapeutic touch. This method does not require special facilities, does not result in costs for the patient, and simply and effectively decreases anxiety $[10,11]$.

\section{Aim of the research}

Therefore, the present study aimed to examine muscle relaxation and therapeutic touch in women candidates for caesarean section to investigate the effect of these therapeutic methods on relaxation in pregnant women and decreasing their anxiety levels.

\section{Material and methods}

This was a clinical trial conducted on 90 pregnant women (45 persons in each of the two groups) who underwent elective caesarean section in Imam Khomeini Hospital, Ahvaz, Iran during 2016.

\section{Inclusion criteria}

All pregnant women had conditions necessitating caesarean delivery, which were evidence for examination and normal pelvic ultrasound and normal laboratory tests. Regarding knowledge, the participating pregnant women were at least able to write.

\section{Exclusion criteria}

History of continuous use of benzodiazepines, antipsychotics, psychotics, opiates, history of anxiety disorders, attacks, or any history of previous psychiatric illness, existence of dystocia and hard delivery in previous pregnancies, existence of any kind of maternal and prenatal risk factor that makes non-elective caesarean section possible, smoking or history of drugs and antidepressants, history of congestive heart failure, asthma, chronic obstructive pulmonary disease (COPD), type I and II diabetes, history of hypertension, received hypertension drugs, and any allergy to food or medicine.

\section{Instruments}

1. The Hamilton Anxiety Rating Scale (HAM-A) that is among the first and most valid scales to measure the intensity of anxiety symptoms and has been used in clinical and research sections. This scale consists of 14 sections; each section contains a series of symptoms related to anxiety. This scale investigates both psychological symptoms of anxiety (mental distress) and physical anxiety (physical pain and complaints). According to the design of this scale, an evaluator (usually a psychologist or clinical psychologist), after clinical observations, classifies different symptoms of anxiety quantitatively. In self-report questionnaires there is a possibility that responses may be under the influence of personal characteristics, but in this scale this problem is rarely observed. Meanwhile, the reliability and validity of this scale were confirmed.

2. A clinical demographic questionnaire was completed based on data obtained from the patient, as well as contents of the case including age, education, marital status, employment, income, gender, smoking, family history of coronary artery disease, and other diseases such as high blood pressure, high 
blood lipids, diabetes, chronic kidney failure, and pulmonary disease.

After selecting the sample, pregnant women were randomly assigned into two groups including an intervention group and a control group. The demographic data were collected during the first interview. Then, the data relating to the interventions were recorded at two steps respectively at $4 \mathrm{~h}$ before surgery and after surgery (during hospitalisation). Then, systolic blood pressure, diastolic blood pressure, radial pulse rate, and number of breaths per minute were measured and recorded carefully.

After evaluating the concerns, information and beliefs regarding caesarean section were studied in three areas of cognitive and behavioural information as follows:

1. Information control: at this step, inaccurate information about the patient was revised, and complementary information about caesarean, its duration, and general conditions of caesarean section were provided for the patient.

2. Cognitive control: according to the cognitive distortions in the patient, cognitive control was performed (e.g. patient's attention to the advantages instead of emphasising the unpleasant aspects).

3. Behavioural control: behavioural control methods including specific breathing exercises, relaxation, and distraction technique were given to the patients for use during times of anxiety.

Progressive muscle relaxation was performed in the intervention group for 20-25 min. These activities were performed every hour and, in sum, a total of four times before the surgery. For the control group, neutral contents were distributed, and no other intervention was performed. Patients were studied within three steps in the Obstetrics and Gynaecology Ward of Imam Khomeini Hospital, and all of these steps were designed by a veteran and knowledgeable researcher. After data collection, data were analysed according to the HAM-A, and the main objectives were studied.

\section{Statistical analysis}

In order to analyse data, using descriptive methods including frequency distribution tables, diagrams, and numerical indexes, variables of interest were described. Also, to investigate the relationship between variables, independent sample $t$-test, paired sample $t$-test, and repeated measurements were used. Data were analysed using SPSS V22.

\section{Results}

Vital characteristics of patients were similar in the two groups of the study (Table 1).

In investigating the relationship between demographic characteristics and the effect of relaxation therapy, the two groups were similar. This means
Table 1. Vital characteristics of patients

\begin{tabular}{|lcc|}
\hline Parameters & $\begin{array}{c}\text { Control } \\
\text { group } \\
27.04 \pm 4.48^{\mathrm{a}}\end{array}$ & $\begin{array}{c}\text { Intervention } \\
\text { group }\end{array}$ \\
\hline Age & $112.13 \pm 4.06^{\mathrm{a}}$ \\
Systolic blood pressure & $74.49^{\mathrm{a}}$ & $114.89 \pm 7.19^{\mathrm{a}}$ \\
$\begin{array}{l}\text { Diastolic blood } \\
\text { pressure }\end{array}$ & $82.38 \pm 6.31^{\mathrm{a}}$ & $77.22 \pm 8.56^{\mathrm{a}}$ \\
$\begin{array}{l}\text { Radial pulse number } \\
\text { per minute }\end{array}$ & $18.09 \pm 1.24^{\mathrm{a}}$ & $17.67 \pm 1.16^{\mathrm{a}}$ \\
$\begin{array}{l}\text { Number of breaths per } \\
\text { minute }\end{array}$ & $\mathrm{a}$ & \\
\hline
\end{tabular}

that subjects were similar in terms of education (elementary, diploma, academic (most of them had diploma)), income (less than 250 dollars, between 250 and 750 dollars, more than 750 dollars (most of them received between 250 and 750 dollars)), number of deliveries (one to five deliveries (most of them were experiencing the first delivery)), and smoking (most of them were not smokers). Investigating the relationship between these parameters and the effect of this technique using $\chi^{2}$ and Pearson tests showed that only income level has a significant relationship with this relaxation therapy $(p>0.05)$.

Investigating the relationship between clinical factors and the effect of relaxation therapy showed that in both case and control groups there is no significant relationship between these parameters and the effect of relaxation therapy $(p<0.05)$.

\section{Comparing explicit anxiety in research groups before caesarean section}

Explicit anxiety levels between research groups before and after caesarean section are presented in Tables 2 and 3, respectively. Explicit anxiety and total anxiety showed a significant difference between research groups, and the anxiety level in the case group was significantly lower than in the control group.

\section{Discussion}

A baby's birth includes a period that starts from the onset of regular uterine contractions and ends with the withdrawal of the pair, and this process is known as labour, which means hardship, suffering, and physical effort [12]. Therefore, the mother experiences a lot of stress and anxiety and is exposed to physical and mental diseases [13]. This stress is especially severe when the mother is exposed to caesarean section. Therefore, the establishment of a suitable context to adjust stress and anxiety can promote the mental health of mothers. In the present study, the effect of relaxation techniques including information, and behavioural and muscle 
Table 2. Comparing anxiety levels between research groups before caesarean section

\begin{tabular}{|lccc|}
\hline Anxiety & Intervention & Control & Sig. \\
$\begin{array}{l}\text { Explicit } \\
\text { anxiety }\end{array}$ & $49.22 \pm 6.75$ & $53.62 \pm 6.98$ & 0.003 \\
$\begin{array}{l}\text { Implicit } \\
\text { anxiety }\end{array}$ & $40.53 \pm 4.50$ & $40.33 \pm 1.18$ & 0.774 \\
Anxiety & $89.76 \pm 9.44$ & $93.96 \pm 7.39$ & 0.021 \\
\hline
\end{tabular}

relaxation techniques on decreasing the anxiety of mothers under caesarean section was investigated. Relaxation is one of the nursing techniques that is known to be a complementary non-drug treatment, creating a balance between the posterior and anterior hypothalamus; it decreases the activity of sympathetic nervous system and with the release of catecholamine, and decreases muscle stress, unpleasant physiological effects, blood pressure, pulse rate, and muscle spasms resulting from stress $[14,15]$.

Investigating the subjects in terms of other demographic characteristics showed that in both groups, most of the subjects had a diploma, income between 250 dollars and 750 dollars, were experiencing the first delivery, and were non-smokers. A significant difference existed between elevated income level and the effect of the relaxation technique $(p>0.05)$.

About clinical factors, most mothers did not have other diseases during pregnancy, such as cardiovascular disease, and caesarean history in their family. Investigating the relationship between clinical factors and the effect of relaxation technique showed no relationship between these factors and the effect of relaxation technique.

In investigating the effect of relaxation technique on decreasing anxiety, the results of this study showed that explicit anxiety in the intervention group was significantly lower than in the control group, but implicit anxiety did not show any difference in research groups. However, the relaxation technique decreased total anxiety in pregnant mothers prior to caesarean. After caesarean, the condition was similar, and this technique decreased explicit anxiety and total anxiety of mothers. Vatankhah [16] states that relaxation based on meditation decreases anxiety among women, and this is consistent with the findings of the present study. Similar results were obtained by Yildirim and Sahin [17], who conducted a study on relaxation techniques through touching. A common reaction in people under stress is to look for people that help them by giving information in dealing with stress and anxiety [18]. In the present study, the results showed that providing mothers with sufficient information regarding caesarean decreases their anxiety and increases their tolerance. Heydari et al. [19] investigated the effect of
Table 3. Comparing anxiety levels between research groups after caesarean section

\begin{tabular}{|lccc|}
\hline Anxiety & Intervention & Control & Sig. \\
$\begin{array}{l}\text { Explicit } \\
\text { anxiety }\end{array}$ & $48.60 \pm 5.68$ & $53.56 \pm 6.99$ & 0.000 \\
$\begin{array}{l}\text { Implicit } \\
\text { anxiety }\end{array}$ & $40.58 \pm 4.42$ & $40.29 \pm 1.29$ & 0.670 \\
Anxiety & $89.19 \pm 8.08$ & $93.84 \pm 7.55$ & 0.006 \\
\hline
\end{tabular}

cognitive behavioural therapy on anxiety of women under intrauterine insemination therapy and stated that anxiety in the intervention group was significantly lower than in the control group. In addition, they stated that the use of cognitive behavioural therapy, besides providing correct information and a true understanding of the location, starts with the effect of muscle relaxation and decreases the number of breaths and leads to nervous relaxation. It is possible to control the anxiety of infertile women under treatment. Ahmadi and Bagheri [20] state that thinking based on education and information plays an important role in decreasing pregnancy problems and fear, and this along with decreasing and limiting the consumption of chemical drugs promotes the health of the mother and the baby. Indeed, information and thinking help the mother to adapt to the conditions and overcome fear and anxiety, and this decreases the risk of complications after giving birth.

Studies have shown that one of the factors that cause delivery pain is disruption of balance in transferring messages through thick and thin fibres to the spinal cord. While transferring messages through thick fibres, pain is not felt. During pain-free stimulation such as massage or relaxation, thick fibres are activated, and if the pain-free stimulation overcomes painful stimulation (e.g. uterine contraction), pain is not felt based on that acute form, and this decreases anxiety in mothers [16]. Such a condition was observed in the present study.

Also, investigations show that muscle relaxation decreases oxygen consumption, increases $\mathrm{CO}_{2}$ disposal, and decreases heartbeat and blood pressure. This, besides decreased energy consumption and muscle contraction, decreases the anxiety and mental pressures of the person [21], which is consistent with decreased anxiety in pregnant women. Jariani et al. [22] investigated the effect of progressive muscle relaxation on anxiety of patients with heart failure. Authors [23] investigated the effect of muscle relaxation and music therapy on the anxiety levels of patients waiting for cardiac catheterisation. Malmir et al. [24] investigated the effect of Benson's relaxation on explicit anxiety of patients waiting for open heart surgery. Ahmadi and Bagheri [20] investigated the effect of training on anxiety, fear, and pain among pregnant 
women. Kordi et al. [25] investigated the effect of information promoter programs on decreasing fear and anxiety of pregnant women.

Also, investigations showed that no significant difference exists between anxiety levels before and after caesarean section in research groups. This means that anxiety existed after caesarean section. Most women feel anxious when they feel pain before a caesarean, and in these conditions, emotional, rational, mental, and physical support can decrease the anxiety of pregnant mothers.

\section{Conclusions}

A relaxation therapy technique was performed on patients with elective caesarean section in three areas of cognitive, behavioural, and muscle relaxation, which decreased the explicit and total anxiety of mothers, and this indicated the benefits of non-drug interventions in decreasing anxiety. In this condition, emotional, rational, mental, and physical support decreases anxiety of pregnant mothers.

\section{Conflict of interest}

The authors declare no conflict of interest.

\section{References}

1. Stuart GW, Laraia MT. Principles and practice of psychiatric nursing. Mosby, St Louis 2001; 275.

2. Yoo HJ, Ahn SH, Kim SB, Kim WK, Han OS. Efficacy of progressive muscle relaxation training and guided imagery in reducing chemotherapy side effects in patients with breast cancer and in improving their quality of life. Support Care Cancer 2005; 13: 826-833.

3. Silverman WK, Kurtines WM, Jaccard J, Pina AA. Directionality of change in youth anxiety treatment involving parents: an initial examination. J Consult Clin Psychol 2009; 77: 474-485.

4. Rickels K, Shiovitz TM, Ramey TS, Weaver JJ, Knapp LE, Miceli JJ. Adjunctive therapy with pregabalin in generalized anxiety disorder patients with partial response to SSRI or SNRI treatment. Int Clin Psychopharmacol 2012; 27: $142-150$.

5. Hidalgo RB, Tupler LA, Davidson JR. An effect-size analysis of pharmacologic treatments for generalized anxiety disorder. J Psychopharmacol 2007; 21: 864-72.

6. Mitte K, Noack P, Steil R, Hautzinger M. A meta-analytic review of the efficacy of drug treatment in generalized anxiety disorder. J Clin Psychopharmacol 2005; 25: 141-150.

7. Arch JJ, Ayers CR, Baker A, Almklov E, Dean DJ, Craske MG. Randomized clinical trial of adapted mindfulnessbased stress reduction versus group cognitive behavioral therapy for heterogeneous anxiety disorders. Behav Res Therapy 2013; 51: 185-196.

8. Gift AG, Moore T, Soeken K. Relaxation to reduce dyspnea and anxiety in COPD patients. Nurs Res 1992; 41: 242-246.

9. Estabrooks CA, Morse JM. Toward a theory of touch: the touching process and acquiring a touching style. J Adv Nursing 1992; 17: 448-456.
10. Feltham M, Taylor E. Therapeutic touch and massage. Nursing Standard 1998; 5: 26-31.

11. Mast D, Meyer J, Urbranks A. Relaxation techniques. Cancer Nurs 2003; 10: 241-247.

12. Kagingham FG, Lonok J, Bloom SL, Hass JC, Espong YK. Pregnancy and Childbirth. Golban Pub, Tehran 2011.

13. Taghiloo $\mathrm{S}$. The effect of the holy Quran reading instruction on stress reduction in the young and adolescents. J Guilan Univ Med Sci 2009; 18: 72-81.

14. Makaremi A. Relation of depression and anxiety to personal and academic problems among Iranian college students. Psychol Rep 2000; 87: 693-8.

15. Newshan G, Schuller-Civitella D. Large clinical study shows value of therapeutic touch program. Holistic Nursing Practice 2003; 17: 189-192.

16. Vatankhah $\mathrm{H}$. The effect of relaxation technique on anxiety of women with the first delivery. Deliv J 2017; 6: 43-56.

17. Yildirim G, Sahin NH. The effect of breathing and skin stimulation techniques on labour pain perception of Turkish women. Pain Res Manag 2004; 9: 183-187.

18. Lotfi H. Social Psychology/The psychology of social conformity (theories and applications). Hamid Lotfi, Tehran 2002.

19. Heydari P, Latifnezhad R, Sahebi A, Jahanian M, Mazloom $\mathrm{S}$. The effect of cognitive behavioral therapy on anxiety of infertile women under IUI treatment. J Fertil Infert 2002; 8: 40-51.

20. Ahmadi L, Bagheri F. The effectiveness of educating mindfulness on anxiety, fear of delivery, pain catastrophizing and selecting caesarian section as the delivery method among nulliparous pregnant women. Nursing Practice Today 2017; 4: 52-63.

21. Sadock BJ, Sadock VA, Kaplan and Sadok's comprehensive textbook of psychiatry. $8^{\text {th }}$ ed. Lippincott Williams and Wilkins, Philadelphia 2000.

22. Jariani M, Saki M, Momeni N, Ebrahimzadehm F, Seyedian A. The effect of progressive muscle relaxation on anxiety of patients with heart failure. Medical University of Lorestan 2011; 3: 27-35.

23. Moghaddam Z. Investigating the effect of muscle relaxation and music therapy on anxiety level of patients waiting for cardiac catheterization. Cardiovasc Nurs J 2012; 4: $22-30$.

24. Malmir M, Teimouri F, Pishgooei A, Dabaghi P. The effect of Benson relaxation on explicit anxiety of patients waiting for open heart surgery. J Nurs Care 2015; 3: 182-190.

25. Kordi M, Bakhshi M, Masoudi S, Esmaily H. Effect of a childbirth psychoeducation program on the level of fear of childbirth in primigravid women. Evid Based Care 2017; 7: 26-34

\section{Address for correspondence:}

\section{Masoumeh Nazarinasab}

Department of Radiology

Golestan Hospital

Ahvaz Jundishapur University of Medical Sciences

6135733118 Ahvaz, Iran

Phone: +98 9166415264

E-mail: drnazarinasabm@gmail.com 